\title{
Safe Spaces on Campus: An Examination of Student and Faculty Perceptions
}

\author{
Kirsten L. Witherup ${ }^{1}$, PJ Verrecchia ${ }^{1}$ \\ ${ }^{1}$ York College of Pennsylvania, USA \\ Correspondence: PJ Verrecchia, York College of Pennsylvania, USA.
}

Received: Apr. 19, $2020 \quad$ Accepted: May 24, $2020 \quad$ Online Published: May 24, 2020

doi:10.11114/jets.v8i6.4874 URL: https://doi.org/10.11114/jets.v8i6.4874

\begin{abstract}
Creating and maintaining a positive school climate is paramount for student well-being. This climate is marked by a teaching and learning environment that can foster positive student outcomes, such as academic achievement, and decrease negative student outcomes, such as absenteeism (Thapa, Cohen, Guffey, \& Higgins-D'Alessandro, 2013). One approach to creating a positive and inclusive school climate that welcomes diversity is the development of safe spaces or safe zones on campus. Given the lack of scholarly literature that addresses this topic, the current study explores safe spaces from the perspective of college students and faculty at a liberal arts institution.
\end{abstract}

Keywords: Safe spaces, safe zones, education, campus climate, logistic regression

\section{Introduction}

Safe spaces (also referred to as safe zones) are a recent controversy on college campuses. In 2016, John (Jay) Ellison, Dean of Students at the University of Chicago, wrote a letter to incoming freshmen welcoming them to the school. In the letter he stated that "we do not support so-called 'trigger warnings,' we do not cancel invited speakers..., and we do not condone....intellectual 'safe spaces"” (Ellison, 2016). In response, Matthew Guterl called Ellison's letter a "cold, Darwinian approach," that incoming students deserved to be received "more graciously," and that the absence of safe spaces is "counter to the very mission of higher education" (Guterl, 2016). Writing for the Harvard Graduate School of Education, Leah Shafer (2016, p. 2) said, "The concepts of 'safe space' and 'free speech' have often seemed at odds. If students call for their campus to be a safe space....are they infringing on the First Amendment rights of other students, faculty, and staff to say and do as they are legally allowed?" Shafer added, "It's complicated."

What is meant by safe spaces on college campuses? Frank Furedi states that the term safe means not just "an absence of danger," but also "virtue... as in safe sex, safe drinking, safe eating, and safe space" all of which "signals responsibility" (2017, p. 10). The term safe spaces first appeared during the women's rights movement, where it meant physical spaces on campus where women's issues could be discussed (Campbell \& Manning, 2018). The term was later used by LGBT groups to refer to a place where sexual minorities could go to discuss LGBT issues without fear of judgment or discrimination (Paxson, 2016).

More recently, examples of safe spaces have included places on campus, such as classrooms, where educators are encouraged to adopt pedagogical approaches that foster a safe environment for students (Coleman, 2016). These spaces should allow students, particularly those who are marginalized, to feel comfortable being expressive about material that impacts them on personal level, rather than feeling ignored (Johnson, 2017). More often, however, safe spaces mean specially designated areas where students are segregated from each other. In 2015, the president of Claremont McKenna College agreed to student demands for a "safe space for students of color" (Glick, 2015). That same year, students at Princeton occupied the president's office and demanded "a dedicated space on campus for black students that is clearly marked" (Knapp, 2015). Here we see safe spaces as a designated area where students are not only free to discuss ideas without fear of retribution, but spaces where people do not have to interact with anyone who does not look like them, because "interacting with the cultural majority causes stress for minorities" (Campbell \& Manning, 2018, p. 80). The president of Northwestern University defended the wishes of black students to not eat lunch with white students (a racially segregated cafeteria) (Schapiro, 2016), and in the United Kingdom certain universities have LGBT only housing, as well as faculty committees where "academic members who are white, male, straight, and have no disability cannot participate in conference discussions" so these meetings can be "unique, safe spaces" (Furedi, 2017, pp. 83-84). 
Notably, there is a lack of scholarly literature that addresses safe spaces or safe zones on campus, and much of the existing work focuses on specific marginalized groups (e.g., students marginalized by race and/ethnicity) and/or employs a qualitative methodological design. Other published work on this topic is solely opinion-based. The current study is a qualitative exploration of safe spaces from the perspective of all college students and faculty at a liberal arts institution in South-Central Pennsylvania, meaning that it is inclusive of both marginalized and non-marginalized individuals. Using a survey tool developed to assess perceptions related to both microaggressions on campus as well as safe spaces, the authors seek to contribute to the small body work on safe spaces by developing a better understanding of: (1) whether or not students and faculty believe safe spaces encourage a positive learning environment; (2) whether or not students and faculty believe campuses should provide designated buffer zones from offensive speech; and (3) whether or not safe spaces detract from learning through the suppression of free speech.

\section{Literature Review}

\section{Safe Spaces on College and University Campuses}

\section{Developing Safe Spaces}

More recently, marginalized students have become increasingly visible at institutions of higher education. It has been suggested, however, that such visibility is not reflected in the activities and programming of these institutions, especially at schools with conservative administration and deeply rooted religious tradition (Coleman, 2016). With a growing concern to foster support for students marginalized by ethnicity, gender, race, sexual orientation, and so on, some research suggests that it is imperative for colleges and universities to do so through the development of safe spaces (Coleman, 2016; Young \& McKibban, 2014).

Some of the current literature on developing safe spaces focuses on lesbian, gay, bisexual, and transgender (LGBT) students (Coleman, 2016; Young \& McKibban, 2014). For instance, Coleman (2016) suggests that in order to create an empowering environment for this population, it is important to consider the influence of staff, faculty, and administration - that these individuals must create formal spaces and engage in other related supportive activities, such as identifying visible allies for LGBT students and forming student organizations. Young and McKibban (2014) discuss safe spaces in relation to "Safe Zones" for LGBT students, which is an educational and interactive workshop that seeks to bring awareness to issues affecting this population. Each workshop is tailored to a college or university and provides a safe space to share experiences, both positive and negative.

\section{Obstacles to Developing Safe Spaces}

While support from key institutional personnel as well as activities and programming can be essential to the development of safe spaces on campus, research highlights various obstacles that can hinder this process. For instance, Coleman (2016), focusing specifically on LGBT students at historically black colleges and universities, finds that a battle for voice, including the lack of acknowledgment of certain groups, and social conservatism negatively impact the creation of safe spaces. Not only do some individuals, such as educators and administrators, not understand the complexities of marginalized populations, "some administrators and faculty were afraid to even use the word homosexual or gay" (Coleman, 2016, p. 8).

According to Young and McKibban (2014), challenges for developing safe spaces can involve self-disclosure in a potentially "mixed group" (i.e., one that involves both LGBT students as well as straight students who are allies) (p. 377). Other concerns related to participant privacy. For instance, the "Safe Zones" workshop discussed above, strives to create an environment that promotes openness for participants, while, at the same time, respects the privacy for those involved. A final example includes tensions among faculty. One faculty member stated that although some faculty had a desire to openly support LGBT students, "as newly hired junior faculty, we were careful about potential consequences (with students, administration, and community members) of being open advocates for LGBT equality" (Young \& McKibban, 2014, p. 379).

\section{Concerns About Safe Spaces}

While some research supports the need for, and development of, safe spaces (Coleman, 2016; Young \& McKibban, 2014), other discourse suggests that today's safe spaces "seem designed mostly to stifle criticism of the majority viewpoints" and that in order "to ensure campus environments remain committed to open inquiry" both campus administrators and trustees must remain committed to, and advocate for, such inquiry (Johnson, 2017, p. 46). While recognizing the need for students to not be re-traumatized, Schroeder (2017) states that speech codes and safe spaces on college campuses, as well as trigger warnings in class syllabi, may have a "chilling effect on free expression on college campuses," and creating environments that are "intolerant of opposing viewpoints" (p. 327). Schroeder believes that safe spaces undermine deliberative democracy by doing away with reciprocity. In other words, by only allowing one side of an issue to be presented, in order to protect students from ideas they find disagreeable, people can never 
"recognize the moral merits in their opponents" (Schroeder, 2017, p. 341.).

\section{Method}

A qualitative survey was created on Qualtrics to measure attitudes about safe spaces and distributed at a private, liberal arts college in South-Central Pennsylvania. The survey, which was delivered to every student and faculty member via email, asked a combination of demographic questions (e.g., sex, race, year in school) and three questions regarding safe spaces on college campuses. The college of approximately 4,500 students is mostly female (53.9\%) and white (78.7\%). Recruiting of respondents started on September 12, 2018 and the survey was closed on October 11, 2018. The data were analyzed using SPSS.

\section{Results}

Over $300(\mathrm{~N}=370)$ students completed the survey. The sample of students was majority White $(83.4 \%)$ and female (59.2\%). The vast majority of the sample (96.4\%) is made up of full time students. Respondents were asked to describe their political beliefs and most of them (43.5\%) said they were a mix of conservative and liberal. Just over one quarter (25.8\%) described themselves as conservative or very conservative, while under one third (30.6\%) described themselves as liberal or very liberal. The average age of students in the sample was 20.76 years $(\mathrm{SD}=4.80)$. See Table 1 for the demographic description of student participants.

Table 1. Student Participant Demographics $(N=370)$

\begin{tabular}{l|l|l|}
\hline Demographic & Frequency & Percent \\
\hline Age & & \\
\hline $18-22$ & 333 & 90.1 \\
\hline $23-27$ & 19 & 5.1 \\
\hline $28-32$ & 7 & 1.8 \\
\hline $33-37$ & 4 & 1.2 \\
\hline 38 and older & 7 & 1.8 \\
\hline Sex & & \\
\hline Male & 151 & 40.8 \\
\hline Female & 219 & 59.2 \\
\hline Race & & \\
\hline American Indian or Alaskan & 3 & 0.7 \\
Native & & \\
\hline Asian & 7 & 1.8 \\
\hline Black & 19 & 5.0 \\
\hline Latino/a & 12 & 3.1 \\
\hline Native Hawaiian or other & 3 & 0.7 \\
Pacific Islander & & \\
\hline White & 309 & 83.4 \\
\hline Other & 20 & 5.3 \\
\hline Academic Major & & \\
\hline Natural Sciences & 54 & 14.7 \\
\hline Social Sciences & 72 & 19.5 \\
\hline Humanities & 32 & 8.7 \\
\hline Engineering & 37 & 9.9 \\
\hline Business & 68 & 18.3 \\
\hline Nursing & 39 & 10.5 \\
\hline Education & 22 & 6.0 \\
\hline Other & 46 & 12.3 \\
\hline Year in School & & \\
\hline Freshman & 111 & 30.1 \\
\hline Sophomore & 78 & 21.0 \\
\hline Junior & 69 & 18.6 \\
\hline Senior & 103 & 27.9 \\
\hline Graduate Student & 9 & 2.4 \\
\hline Student Status & 357 & \\
\hline Full time & 13 & 96.4 \\
\hline Part time & 33 & 3.6 \\
\hline Political Beliefs & 80 & \\
\hline Very liberal & 161 & 9.0 \\
\hline Liberal & 79 & 21.6 \\
\hline Mix of liberal/conservative & 17 & 43.5 \\
\hline Conservative & 21.3 \\
\hline Very conservative & 4.5 \\
\hline & \\
\hline & & \\
\hline & & \\
\hline
\end{tabular}


In addition, 90 faculty members completed the survey. The sample of faculty was also majority White (94.4\%) and male $(50 \%)^{1}$. Over half of the faculty surveyed $(52.2 \%)$ described their political beliefs as liberal or very liberal, 20 percent described themselves as conservative or very conservative, and over one quarter $(27.8 \%)$ described their political beliefs as a mix of liberal and conservative. The average age of the faculty in the sample was 48.79 years $(\mathrm{SD}=12.12)$. See Table 2 for the demographic description of faculty participants.

Table 2. Faculty Participant Demographics $(N=90)$

\begin{tabular}{|c|c|c|}
\hline Demographic & Frequency & Percent \\
\hline \multicolumn{3}{|l|}{ Age } \\
\hline $30-39$ & 25 & 27.8 \\
\hline $40-49$ & 25 & 27.8 \\
\hline $50-59$ & 21 & 23.3 \\
\hline $60-69$ & 14 & 15.5 \\
\hline Over 70 & 5 & 5.6 \\
\hline \multicolumn{3}{|l|}{ Sex } \\
\hline Male & 45 & 50.0 \\
\hline Female & 43 & 47.8 \\
\hline \multicolumn{3}{|l|}{ Race } \\
\hline Asian & 1 & 1.1 \\
\hline Black & 2 & 2.2 \\
\hline Latino/a & 1 & 1.1 \\
\hline White & 85 & 94.4 \\
\hline Other & 1 & 1.1 \\
\hline \multicolumn{3}{|l|}{ Academic Discipline } \\
\hline Natural Sciences & 7 & 7.8 \\
\hline Social Sciences & 35 & 38.9 \\
\hline Humanities & 16 & 17.8 \\
\hline Engineering & 6 & 6.7 \\
\hline Business & 9 & 10.0 \\
\hline Other & 17 & 18.9 \\
\hline \multicolumn{3}{|l|}{ Rank } \\
\hline Adjunct Professor & 31 & 34.4 \\
\hline Assistant Professor & 21 & 23.3 \\
\hline Associate Professor & 18 & 20.0 \\
\hline Full Professor & 9 & 10.0 \\
\hline Instructor & 11 & 12.2 \\
\hline \multicolumn{3}{|l|}{ Political Beliefs } \\
\hline Very liberal & 19 & 21.1 \\
\hline Liberal & 28 & 31.1 \\
\hline Mix of liberal/conservative & 25 & 27.8 \\
\hline Conservative & 15 & 16.7 \\
\hline Very conservative & 3 & 3.3 \\
\hline
\end{tabular}

Survey participants were asked to respond to three Likert scale statements to examine attitudes toward safe spaces on college campuses. The first stated: "Safe spaces encourage a positive learning environment where students feel included and respected," and it was coded as strongly disagree (1), disagree (2), neither agree nor disagree (3), agree (4) and strongly agree (5). The second stated: "Colleges and universities should have safe spaces on campus as designated buffer zones from speech that I find offensive," and was coded as strongly disagree (1), disagree (2), neither agree nor disagree (3), agree (4) and strongly agree (5). The third stated: "Safe spaces detract from learning through the suppression of free speech and was coded as strongly disagree (1), disagree (2), neither agree nor disagree (3), agree (4) and strongly agree (5). However, for analysis, responses were reverse coded, because it stands to reason that someone who strongly agrees with the first two statements would strongly disagree with the last statement.

Almost 50 percent $(46.5 \%)$ of students agreed or strongly agreed that safe spaces encourage a positive learning environment, and over half of the sample (52.5\%) disagreed or strongly disagreed that colleges and universities should have safe spaces on campus. Under one half of students $(40.8 \%)$ agreed or strongly agreed that safe spaces detract from learning. The results for each Likert scale statement for students can be found in Table 3. The responses were combined

1 Slightly less than half of the sample was female (47.8\%), and two faculty members $(2.2 \%)$ did not provide a sex. 
to create a safe spaces index to use as the dependent variable. The Cronbach's alpha for this index was .847 , indicating a relatively high internal consistency among the included items.

Table 3. Safe Spaces Statements (Students)

\begin{tabular}{l|l|l}
\hline Statement & Frequency & Percent \\
\hline $\begin{array}{l}\text { Encourage a positive learning } \\
\text { environment }\end{array}$ & & \\
\hline Strongly disagree & 74 & 20.0 \\
\hline Disagree & 45 & 12.2 \\
\hline Neither agree nor disagree & 79 & 21.4 \\
\hline Agree & 112 & 30.3 \\
\hline Strongly agree & 60 & 16.2 \\
\hline Colleges and universities should & & \\
\hline have safe spaces & & 35.7 \\
\hline Strongly disagree & 132 & 16.8 \\
\hline Disagree & 62 & 29.2 \\
\hline Neither agree not disagree & 108 & 13.5 \\
\hline Agree & 50 & 4.9 \\
\hline Strongly agree & 18 & \\
\hline $\begin{array}{l}\text { Safe spaces detract from } \\
\text { learning }\end{array}$ & & 5.7 \\
\hline Strongly disagree & 21 & 26.8 \\
\hline Disagree & 99 & 26.8 \\
\hline Neither agree nor disagree & 99 & 20.3 \\
\hline Agree & 75 & 20.5 \\
\hline Strongly agree & 76 & 525 \\
\hline
\end{tabular}

Just over 40 percent (43.5\%) of the faculty agreed or strongly agreed that safe spaces encourage a positive learning environment, and over 50 percent of the sample (53.3\%) disagreed or strongly disagreed that colleges and universities should have safe spaces on campus. Under 40 percent of the faculty $(37.8 \%)$ disagreed or strongly disagreed that safe spaces detract from learning. The results for each Likert scale statement for the faculty can be found in Table 4 . The responses of the faculty were combined to create a safe spaces index to use as the dependent variable. The Cronbach's alpha for this index was a robust .901 .

Table 4. Safe Spaces Statements (Faculty)

\begin{tabular}{l|l|l}
\hline Statement & Frequency & Percent \\
\hline $\begin{array}{l}\text { Encourage a positive learning } \\
\text { environment }\end{array}$ & & \\
\hline Strongly disagree & 11 & 12.2 \\
\hline Disagree & 11 & 12.2 \\
\hline Neither agree nor disagree & 29 & 32.2 \\
\hline Agree & 26 & 28.9 \\
\hline Strongly agree & 12 & 14.4 \\
\hline $\begin{array}{l}\text { Colleges and universities should } \\
\text { have safe spaces }\end{array}$ & & \\
\hline Strongly disagree & 24 & 26.7 \\
\hline Disagree & 24 & 26.7 \\
\hline Neither agree not disagree & 20 & 22.2 \\
\hline Agree & 17 & 18.9 \\
\hline Strongly agree & 5 & 5.6 \\
\hline $\begin{array}{l}\text { Safe spaces detract from } \\
\text { learning }\end{array}$ & & \\
\hline Strongly disagree & 9 & 10.0 \\
\hline Disagree & 25 & 27.8 \\
\hline Neither agree nor disagree & 28 & 31.1 \\
\hline Agree & 17 & 18.9 \\
\hline Strongly agree & 11 & 12.2 \\
\hline
\end{tabular}

The dependent variable was then dichotomized in order to run logistic regression models. The goal is to determine if there are differences in attitudes toward safe spaces on campus based on student and faculty demographic characteristics such as political beliefs, age, race, academic major, academic discipline, and so on. A dichotomized index predicts 
attitudes toward safe spaces (favorable or unfavorable). Logistic regression was used because it explains and predicts relationships between a binary dependent variable and one or more variables measured at any level (Heiman, 2014; Tabachinick \& Fiddel, 2017; Weisburd, 1998).

Regression results for the safe spaces student model indicate that the overall model was statistically reliable (Model $\chi^{2}$ $(5)=106.369, p<.05$ ). The safe spaces model correctly predicted $71.4 \%$ of the responses. The model revealed that students who described their political beliefs as liberal were more likely to think that safe spaces on campus are a good thing than students who described their political beliefs as conservative $(\beta=-.935, \mathrm{p}<.05)$. In addition, females were more likely than males to view safes spaces on campus as positive $(\beta=1.747, p<.05)$. Liberals were about $40 \%$ more likely than conservatives to support safe spaces on campus than conservatives $(\operatorname{Exp}(B)=.392)$, and women were almost six times more likely than men to support safe spaces on campus $(\operatorname{Exp}(B)=5.737)$. The results of this model can be found in Table 5.

Table 5. Logistic Regression Results for Safe Spaces (Students)

\begin{tabular}{l|l|l|l|l|l|l}
\hline Variable & B & S.E. & Wald & df & Sig. & Exp(B) \\
\hline Age & -.367 & .479 & .586 & 1 & .444 & .693 \\
\hline Politics* & -.935 & .174 & 29.024 & 1 & .000 & .392 \\
\hline $\begin{array}{l}\text { Year in } \\
\text { School }\end{array}$ & -.203 & .479 & .179 & 1 & .672 & .816 \\
\hline Race & -.162 & .120 & 1.827 & 1 & .177 & .850 \\
\hline Sex* & 1.747 & .262 & 44.533 & 1 & .000 & 5.737 \\
\hline Constant & .499 & .986 & .256 & 1 & .613 & 1.647 \\
\hline
\end{tabular}

Model Chi-Square $=106.39$

Nagelkerke $\mathrm{R}^{2}=.335$

$* \mathrm{p}<.001$

Regression results for the safe spaces faculty model indicate that the overall model was not statistically reliable (Model $\left.\chi^{2}(6)=14.928, p=.061\right)$. None of the demographic characteristics of faculty members could reliably predict attitudes toward safe spaces. The results of this model can be found in Table 6 .

Table 6. Logistic Regression Results for Safe Spaces (Students)

\begin{tabular}{l|l|l|l|l|l|l}
\hline Variable & B & S.E. & Wald & df & Sig. & Exp(B) \\
\hline Race & .913 & 1.597 & .327 & 1 & .567 & 2.492 \\
\hline Politics & -.987 & .762 & 1.680 & 1 & .195 & .373 \\
\hline Age & -.045 & .050 & .808 & 1 & .369 & .956 \\
\hline Sex & 1.628 & .846 & 3.696 & 1 & .055 & 5.082 \\
\hline Discipline & -.084 & .299 & .978 & 1 & .780 & .920 \\
\hline Rank & .719 & .690 & 1.086 & 1 & .297 & 2.052 \\
\hline
\end{tabular}

Model Chi-Square $=14.928$

Nagelkerke $\mathrm{R}^{2}=.371$

Ap $<.10$

The index scores range from 3 (strongly disagreeing with each statement) to 15 (strongly agreeing with each statement). Since the purpose of this paper is to examine student and faculty attitudes toward safe spaces, means for each index were calculated and a Pearson's Product Moment Correlation Coefficient was calculated which demonstrated a positive but weak statistically significant relationship $(\mathrm{r}=.192, \mathrm{p}<.05)$. An independent samples t-test was then calculated comparing the mean score of the student index $(\mathrm{M}=8.76 \mathrm{SD}=3.26)$ with the mean score of the faculty index $(\mathrm{M}=8.22$, $\mathrm{SD}=3.08)$. No statistically significant difference was found $(\mathrm{t}(458)=1.54, \mathrm{p}<.05)$. It appears that when it comes to having safe spaces on this particular campus, the students and faculty are in agreement. That the mean score for each index was around 8.0 indicates that both students and faculty can be described as middle of the road on this issue.

Of interest are the findings related to attitudes of students and faculty toward having safe spaces on campus. Both students $(46.5 \%)$ and faculty $(43.3 \%)$ agreed or strongly agreed that safe spaces create a positive learning environment, and students (32.5\%) and faculty (37.8\%) disagreed or strongly disagreed that safe spaces detract from learning (the highest percentages for each statement). However, both students $(52.5 \%)$ and faculty $(53.4 \%)$ disagreed that there 
should be safe spaces on campus. The obvious question, and one for further investigation, is why if safe spaces are seen by a plurality of students and faculty as a positive, would the majority of each group not want them on campus? Perhaps, it could be due to current campus norms (as there are not designated safe spaces on the campus in this study), or the way the issue is portrayed in the media as on that is polarizing.

\section{Discussion}

Overall, findings reveal that a plurality of student and faculty respondents view safe spaces favorably - that they encourage a positive learning environment and do not detract from learning. However, despite an overall positive perspective toward safe spaces, results also suggest that the majority of the sample did not support having designated safe spaces on campus. Regression results identified these students as mostly female and politically liberal, and results for the faculty did not identify any demographic characteristics associated with attitudes toward safe spaces.

Based on data from the current study, it is not possible to determine why respondents favored safe spaces but did not support having them on campus. Perhaps these findings are indicative of the obstacles to developing, and concerns about, safe spaces discussed in previous scholarship. More specifically, that barriers in the creation of safe spaces can be rooted in a number of factors (e.g., a lack of understanding about the complexities of marginalized populations; Coleman, 2016), and while some individuals would agree that safe spaces are a good idea in theory, in practice today's safe spaces might represent a threat to, or stifle criticism of, viewpoints of those in the majority (Johnson, 2017).

\section{Limitations}

Despite contributions methodologically and otherwise to the existing empirical work on safe spaces on college and university campuses, the current study must also address potential limitations. One such issue, as highlighted by study findings, involves the survey instrument used in this research. In future iterations of this work, or work by others, it would be beneficial not only to develop an understanding of support (or not) for having safe spaces, but also, if support is not indicated, allowing space for an explanation of why not. Other limitations could include the lack of diversity with regard to survey respondents. As noted, the sample of students was mostly White (83.5\%), as was the sample of faculty members (94.4\%). It is possible that lacking sample diversity, the opinions of additional marginalized group members could have impacted the results of the current work. Also, future research should focus on more than one college or university ${ }^{2}$.

Another limitation is the low response rate. There are roughly 4,500 students at this college, so if 370 took part in the survey the response rate is slightly above eight percent $(8.2 \%$ ). In addition, there are 461 faculty members (full and part time) at this college, making the faculty response rate $19.5 \%$. One issue with using email or web based surveys is nonresponse bias (Sue \& Ritter, 2007). Wells and colleagues administered a survey on a campus using both pen and paper surveys in classrooms and on the school's web site and found a much lower response (13.8\%) with the electronic survey than the classroom survey (96.9\%) (2012). It is possible that over $90 \%$ of the students and $80 \%$ of the faculty at this particular school have no interest in safe spaces, but prior research (see Groves, 2006) has indicated that low response rates do not necessarily mean bias toward the subject.

\section{Policy Implications and Conclusions}

While it is clear that more scholarship on safe spaces is needed to properly address policy implications, it can be suggested from the current findings and other literature that addressing the needs of marginalized students through safe spaces encourages a positive learning environment. While the creation of these spaces was not supported by the majority of the sample in this study, other studies would argue that safe spaces are a requirement to improve campus climates (e.g., Coleman, 2016). Such spaces can promote long-term change in addressing the needs of marginalized students by building a community that allows for natural expression (Coleman, 2016), exploration and empowerment (Coleman, 2016; Young \& McKibban, 2014), as well as advocacy among students, faculty, and administration for social change (Young \& McKibban, 2014).

\section{References}

Campbell, B., \& Manning, J. (2018). The Rise of Victimhood Culture: Microaggressions, Safe Spaces, and the New Culture Wars. London: Palgrave Macmillan. https://doi.org/10.1007/978-3-319-70329-9

Coleman, K. (2016). The difference safe spaces make: The obstacles and rewards of fostering support for the LGBT community at HBCUs. SAGE Open. https://doi.org/10.1177/2158244016647423
Ellison,
J. (2016).
Dear
class
of
2020
student.

\footnotetext{
2 This study reached out to several colleges and universities. Given the low response rates, other schools were excluded from the current analysis.
} 
https://news.uchicago.edu/sites/default/files/attachments/Dear_Class_of_2020_Students.pdf, retrieved on November 11, 2018.

Furedi, F. (2017). What's Happened to the University? A Sociological Exploration of Its Infantalization. New York: Routledge. https://doi.org/10.4324/9781315449609

Glick, S. (2015). Safe Spaces Segregate the Claremont Colleges. The Claremont Independent, November 17, https://claremontindependent.com/safe-spaces-segregate-the-claremont-colleges/, retrieved on November 12, 2018.

Groves, R. M. (2006). Nonresponse rates and nonresponse bias in household surveys. Public Opinion Quarterly, 70, 646-675. https://doi.org/10.1093/poq/nfl033

Guterl, M. P. (2016). Students Deserve Safe Spaces on Campus (essay). Inside Higher Ed, p. 1-4. https://www.insiderhighered.com/views/2016/08/29/stuents-deserve-safe-spaces-campus-essay, retrieved on February 24, 2017.

Heiman, G. H. (2014). Basic Statistics for the Behavioral Sciences. Belmont, CA: Wadsworth.

Johnson, K. C. (2017). Safe spaces and defending the academic status quo. Academic questions, 30(1), 39-46. https://doi.org/10.1007/s12129-016-9611-7

Knapp, K. (2015). Black Justice League at Princeton University Stages Sit-In, Demands School remove Woodrow Wilson's Name from Buildings. Planet Princeton, November 18, https://planetprinceton.com/2015/11/18/black-justice-from-buildings/, retrieved on November 12, 2018.

Paxson, C. (2016). Brown University President: A Safe Space for Freedom of Expression. Washington Post, September 5 .

https://www.washingtonpost.com/opinions/brown-university-president-safe-spaces-dont-threaten-freedom-of-expr ession-they-protect-it/2016/09/05/6201870e-736a-11e6-8149-b8d05321db62_story.html?noredirect=on\&utm_term $=.1 \mathrm{a} 13559 \mathrm{~d} 268 \mathrm{a}$, retrieved on November 12, 2018.

Schapiro, M. (2016). I'm Northwestern's President. Here's Why Safe Spaces for Students are Important. Washington Post, $\quad$ January 15. https://www.washingtonpost.com/opinions/how-to-create-inclusive-campus-communities-first-create-safe-places/2 016/01/15/069f3a66-bb94-11e5-829c-26ffb874a18d_story.html?utm_term=.02aff2f75bbc, retrieved November 12, 2018.

Schroeder, N. (2017). Avoiding deliberation: Why the "safe space" campus cannot Comport with deliberative democracy. Brigham Young University Education and Law Journal, 2017(2), 325-358.

Shafer, L. (2016). Safe space vs free speech: Engaging in difficult conversations to find new approaches to controversial issues. Harvard Graduate School of Education, https://www.gse.harvard.edu/news/uk/16/05/safe-space-vs-free-speech, retrieved on February 24, 2017.

Sue, V. M., \& Ritter, L. A. (2007). Conducting Online Surveys. Los Angeles: Sage. https://doi.org/10.4135/9781412983754

Tabachnick, B. G., \& Fiddell, L. S. (2007). Using Multivariate Statistics (5th ed.) Boston: Allyn \& Bacon.

Thapa, A., Cohen, J., Guffey, S., \& Higgins-D'Alessandro, A. (2013). A review of school climate research. Review of Educational Research, 83, 357-385. https://doi.org/10.3102/0034654313483907

Weisburd, D. (1998). Statistics in Criminal Justice. Belmont, CA: Wadsworth.

Wells, W., Cavanaugh, M. R., Bouffard, J. A., \& Nobles, M. R. (2012). Non-response bias with a web-based survey of college students: Differences from a classroom survey about carrying concealed handguns. Journal of Quantitative Criminology, 28, 455-476. https://doi.org/10.1007/s10940-011-9148-4

Young, S. L., \& McKibban, A. R. (2014). Creating safe places: A collaborative autoethnography On LGBT social activism. Sexuality \& Culture, 18(2), 361-384. https://doi.org/10.1007/s12119-013-9202-5

\section{Copyrights}

Copyright for this article is retained by the author(s), with first publication rights granted to the journal.

This is an open-access article distributed under the terms and conditions of the Creative Commons Attribution license which permits unrestricted use, distribution, and reproduction in any medium, provided the original work is properly cited. 